\title{
Using Goodwill Impairment To Effect Earnings Management During SFAS No. 142's Year Of Adoption And Later
}

Charles E. Jordan, (E-mail: Jordan@cba.usm.edu), University of Southern Mississippi Stanley J. Clark, (E-mail: clark@cba.usm.edu), University of Southern Mississippi Carol E. Vann, (E-mail: DerWeberVann@aol.com), University of Memphis

\begin{abstract}
Prior research (Bens and Heltzer, 2004) shows that the market penalizes firms less for reporting goodwill write-downs below-the-line than it does for presenting them above-the-line. Only in 2002, the year SFAS No. 142 became effective, did goodwill impairments enjoy below-the-line treatment. The current research provides evidence that firms "cherry picked" this year to recognize large impairment losses, thus removing much of the burden from future years when these losses otherwise would have been reported above-the-line. The study also indicates that, even though the number of firms taking goodwill write-offs declined subsequent to 2002, those entities that did so seemed to be taking these discretionary hits because earnings were already depressed in the current year. As such, the big bath earnings management observed in the year of adoption in previous studies (Jordan and Clark, 2004 and 2005) appears to continue even though these impairment losses no longer receive favorable below-the-line treatment.
\end{abstract}

\section{INTRODUCTION}

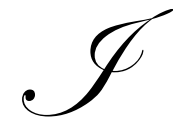

n 2002, SFAS No. 142, Accounting for Goodwill and Other Intangible Assets, drastically altered the accounting procedures for goodwill. Gone is the decades old tradition that existed under APB Opinion No. 17, Intangible Assets, of amortizing goodwill as an operating expense over a period of time not to exceed 40 years. The FASB's belief that goodwill does not necessarily decline in value on a routine basis but rather has an indeterminate life led to their conclusion in SFAS No. 142 that goodwill should not be amortized but instead must be tested at least annually for impairment.

However, goodwill impairment testing under SFAS No. 142 is fraught with managerial discretion and subjectivity. Goodwill is tested for impairment not at the entity level but rather at the reporting unit level. Thus, leeway exists in allocating the existing goodwill among the reporting units. If the carrying value of a reporting unit exceeds its fair value, this fair value must be assigned to the identifiable net assets in the unit. Any remaining (i.e., unassigned) fair value represents the implied value of the goodwill, which is compared to the carrying value of the unit's goodwill to ascertain the amount of any impairment loss. Thus, fair values must be determined not only for the entire reporting unit but also for assets and liabilities within that unit. Judgments concerning these subjectively determined fair values directly affect both the likelihood of reporting a goodwill impairment and its amount.

Massoud and Raiborn (2003) note that the managerial discretion allowed in applying the goodwill impairment test under SFAS No. 142 may lower the quality of earnings figures. The authors state that SFAS No. 142 creates several avenues for earnings management. One of these is employing the "big bath" whereby a company takes a large hit to earnings in a period when income is already depressed. Massoud and Raiborn (2003, p. 30) note that "managers may reason that taking an impairment loss could not make a significant difference in such a period [but] . . 
. could provide massive future income statement benefits." Prior research (i.e., Jordan and Clark, 2004 and 2005) provides strong evidence that this type of earnings management occurred with respect to the reporting of impairment losses in 2002, the year SFAS No. 142 was implemented.

In 2002, the goodwill impairment loss was reported as a cumulative effect from changing an accounting principle and, thus, had no effect on a company's operating income. This below-the-line treatment gave management extra incentive to recognize a goodwill impairment in the year of adoption as any impairment loss subsequent to 2002 would flow through operating income. The current article analyzes the reporting of goodwill impairment losses in 2002, 2003, and 2004 to further examine the presence of earnings management in the year of adoption and to determine if earnings management persists in periods after the favorable below-the-line treatment disappeared. Results suggest that management selectively chose 2002 to recognize relatively large impairment losses, likely because of the favorable reporting treatment enjoyed in that year. In addition, subsequent to 2002 it appears that goodwill impairments continue to be used as a method of big bath earnings management even though these discretionary write-downs now carry a stiffer reporting penalty than they did in the year of adoption.

\section{PRIOR LITERATURE}

Much of the previous literature on SFAS No. 142 dealt with technical issues surrounding its implementation and the intricacies associated with goodwill impairment testing (e.g., see Mercer et al., 2002; Bukics and Chapman, 2002). Herz et al. (2001) and Lander and Reinstein (2003) discuss the different valuation models that can be used to estimate fair value in testing goodwill for impairment. Herz et al. (2001) notes that the residual nature of goodwill complicates its interpretation. Does the goodwill (i.e., residual fair value) exist because of a prior acquisition or does it relate to goodwill internally generated by the entity? In reality, it results from both. Yet, SFAS No. 142 treats the entire goodwill amount as though it is acquired goodwill. Thus, the impairment test under the standard may create results lacking true meaning. For example, an entity might have an existing goodwill balance from a prior acquisition and this acquired goodwill may now be worthless. However, because the firm generated goodwill internally, either before or after the acquisition, the goodwill impairment test under SFAS No. 142 might result in no write-down. The consequence is an impediment to good financial reporting for two reasons. First, no impairment loss is recorded on the acquired goodwill when it is the FASB's intention that such be done. Second, internally generated goodwill, which should not be capitalized under current GAAP, is effectively recorded, thus hindering the comparability of financial reporting among entities. That is, some firms end up with capitalized internally generated goodwill costs while others not in the situation described above expense these costs as incurred.

In addition to the problem just noted with SFAS No. 142's impairment testing, Herz et al. (2001) state that any measurement error in computing the fair value of net assets directly affects the imputed value of the goodwill. This, in turn, impacts the amount of the impairment loss recorded. Such measurement errors could be unintentional or they could be designed for certain outcomes. Massoud and Raiborn (2003, p. 31) note that, with the critical judgments required by management and their appraisal teams, companies may be able to "choose the points in time to recognize impairment losses in a manner that selectively ... fits their operating results." For example, if a company's earnings for the current period are expected to exceed analysts' forecasts, management may decide to record an impairment loss currently to smooth earnings. Alternatively, Massoud and Raiborn (2003) point out that management could decide to report an impairment loss when earnings are already expected to be depressed. It is precisely this form of earnings management, known as the big bath, that is a primary subject of investigation in the present study.

McNichols and Wilson (1988) indicate that firms may use discretionary provisions to manage earnings downward when income is already low. The premise is that taking a large provision in the current period relieves future years of the burden. There is perceived to be only slight harm in lowering the current depressed earnings further because the additional reduction in income generates little incremental punishment by the market. As Chai and Tung (2002, p. 1339) note, management makes "the most of a bad situation by making things a little worse" in the current period to enhance future earnings. Numerous studies examining different types of loss provisions (e.g., extraordinary items, warranty expenses, valuation allowances for deferred tax assets, etc.) provide evidence that big bath earnings management occurs in practice (e.g., see Peek, 2004; Chenheitner and Melumad, 2002; Visvanathan, 1998; Walsh et al., 1991). 
More importantly for the current study, Jordan and Clark (2004) show that the Fortune 100 firms practiced big bath earnings management with respect to reporting goodwill write-downs in the year SFAS No. 142 was adopted (i.e., 2002). Consistent with the big bath theory, firms reporting these discretionary losses had much lower currentperiod earnings than did entities not recognizing such impairments. Although depressed earnings may be viewed as a sign that goodwill has indeed been impaired, Jordan and Clark (2004) note that substandard earnings for the current period only would likely not support this contention. Typically, goodwill does not evaporate overnight, and several periods of depressed earnings would be needed to suggest that goodwill is impaired. Yet, Jordan and Clark (2004) found that, generally, for the firms reporting an impairment loss in 2002 the substandard earnings existed only for that year and not for prior periods, which strongly suggests that the impairments were recognized because of the already depressed earnings in the current period.

Elliott and Shaw (1988) indicated that firms taking big baths tend to be larger than entities not engaging in this form of earnings management. To test this theory in relation to goodwill impairment losses, Jordan and Clark (2005) replicated their study of the Fortune 100 companies with a sample of publicly-traded firms significantly smaller than the nation's 100 largest entities. The results were the same. Companies seemed to record an impairment loss in 2002 because their earnings were already depressed and, thus, it was an opportune time to take a hit to income.

The two prior studies by Jordan and Clark (2004 and 2005) examined goodwill impairments for one year only (i.e., 2002, the implementation year for SFAS No. 142). Companies had an additional incentive to recognize goodwill impairments in 2002 since they were reported below-the-line as a cumulative effect from changing an accounting principle. Subsequent to 2002, impairment losses recorded under SFAS No. 142 must be presented abovethe-line, thus reducing operating income. Beatty and Weber (2006) demonstrate that managers consider the distinction between above-the-line and below-the-line presentation to be important and that preferences between the two are affected by many factors, including a firm's debt contracting, management's bonus schemes, management's tenure with the entity, and exchange delisting incentives.

Bens and Heltzer (2004) show that the market's reactions to goodwill impairments reported below-the-line are much less negative than its reactions to write-downs presented as part of operating income. It is possible that management anticipated the market's reactions to the placement of goodwill impairment losses on the earnings statement and that this enticed them to take larger write-downs in the year of adoption rather than waiting until a later period when they expected the market penalty would be greater. If they did so, strong evidence exists not only of earnings management in the year of adopting SFAS No. 142 but in subsequent years as well. The current study examines this critical issue.

In addition to testing for discrepancies in the amount of impairment losses reported in 2002 versus later years, the present study also examines impairment losses recognized solely in periods after the year of adoption to determine if big bath earnings management persists in spite of the unfavorable reporting treatment such losses now receive. More specifically, has the negative (i.e., above-the-line) reporting treatment of goodwill write-downs been an important enough deterrent to stop the big bath earnings management that Jordan and Clark (2004 and 2005) observed in 2002 when these impairment losses were presented in a more benign manner?

\section{METHODOLOGY}

To accomplish the study's objectives, selected financial statement data were collected on the Fortune 200 companies for the four-year period 2001 through 2004. The Fortune 200 companies were selected for study primarily because they are large firms and, as such, are likely to have goodwill recorded. This restricted sample limits the generalizability of the study's findings, but as with any research, time and resource constraints dictated that sacrifices be made. In addition, Jordan and Clark (2005) show that smaller firms exhibited patterns of earnings management with respect to goodwill impairments in 2002 similar to larger firms. Thus, there is no a priori reason to believe that small firms would differ from large entities in reporting impairment losses subsequent to the year of adoption.

For each of the four years for all companies, the goodwill balance was determined as well as the amount of any impairment loss reported. Amounts were also collected for total assets, sales, total liabilities, and income from 
continuing operations. Data were collected from the firms' $10-\mathrm{k}$ reports made available on the SEC's electronic database (i.e., EDGAR). A key purpose of this study is to determine if management took advantage of the favorable reporting treatment for impairment losses available in 2002. That is, did management "cherry pick" the year to report goodwill impairments. To ascertain this, the group of firms with impairment losses was separated into two subsamples. One sample included firms that reported cumulative effect losses in 2002, while the other one comprised firms that did not report impairment losses in 2002 but did so in a subsequent year (i.e., 2003 or 2004). Ceteris paribus, there is no reason to suspect that the amount of the impairment losses should have differed between the groups of firms simply because the impairments were recorded in different years. However, all things are not equal or constant because management had a real incentive to report the impairment losses in the year of adoption. If the impairment losses recorded in 2002 are significantly larger than those reported in 2003 and 2004, strong evidence exists indicating that management selectively chose the most beneficial period to report the write-down to manage earnings both in the year of adoption and in later periods when the penalty for reporting impairments was more severe.

To determine if big bath earnings management persists subsequent to the year of adoption, the financial characteristics of firms reporting impairment losses in 2003 and 2004 are compared to companies not reporting impairments in those years. If, relative to the non-impairment firms, the impairment firms reported significantly lower earnings in the year of the impairment loss but not in prior periods, then compelling evidence exists that big bath earnings management continues despite the more punitive reporting treatment now in place.

\section{RESULTS}

Of the Fortune 200 companies, data were not consistently available on EDGAR for nine firms generally because they were not publicly traded or because they underwent significant changes during the period of study (e.g., were acquired by another firm). Of the remaining 191 entities, 162 (84.8\%) reported a goodwill balance in their 2001 fiscal year ending financial statements. For these 162 firms, the median amount of goodwill to total assets at the 2001 year end was $7.67 \%$. Thus, a large portion of the sample reported goodwill prior to the implementation of SFAS No. 142 and, generally, the goodwill balance for these firms was material in amount.

Of the 162 firms with goodwill balances, $52(32.1 \%)$ reported a goodwill impairment loss as a cumulative effect from changing an accounting principle in their 2002 earnings statement. Only $20(12.3 \%)$ of the 162 firms reported no cumulative effect in 2002 but recognized an impairment loss in either 2003 or 2004. Clearly, a much larger number of firms recorded a below-the-line impairment loss in 2002 than reported a more punitive above-theline loss in a subsequent period. Intuitively, this suggests that managers took advantage of the favorable treatment afforded impairment losses in 2002 and "cleared the decks" for future periods. However, it does not necessarily prove that earnings were managed as it is logical to assume that more write-downs would have occurred in the year of adoption than in later years irrespective of the reporting treatment of the impairment losses. More specifically, because 2002 was the initial year for impairment testing, it is likely that some impairments that had occurred in prior years but went unrecorded in those years were recognized in 2002. Thus, the incidence or rate of goodwill writedowns should have been higher in 2002 than in 2003 and 2004.

Although there is basis to believe the number of impairments reported should have been higher in 2002 than in subsequent periods, there is no a priori reason to think that, absent earnings management, the dollar amounts recorded as impairment losses in 2002 should have differed from the amounts reported in 2003 and 2004 . If a company reported an impairment loss in the year of adoption (2002), it is of course reasonable to assume that any goodwill write-down in 2003 or 2004 for that firm would be less because some of the decline in value had been previously recorded. However, in our analysis, firms that reported impairment losses in 2002 were excluded from the sample of firms recognizing impairments in 2003 or 2004 to prevent this bias from occurring. For both groups, those reporting impairments in 2002 and those presenting write-downs in a later period, the amount of the impairment loss related to the initial year a loss was recognized. Table 1 provides summary statistics for the amount of goodwill and the impairment loss reported for these two distinct groups of firms. 
Table 1

A Comparison of Firms Reporting Impairment Losses in 2002 with Those Reporting Impairment Losses in Later Years

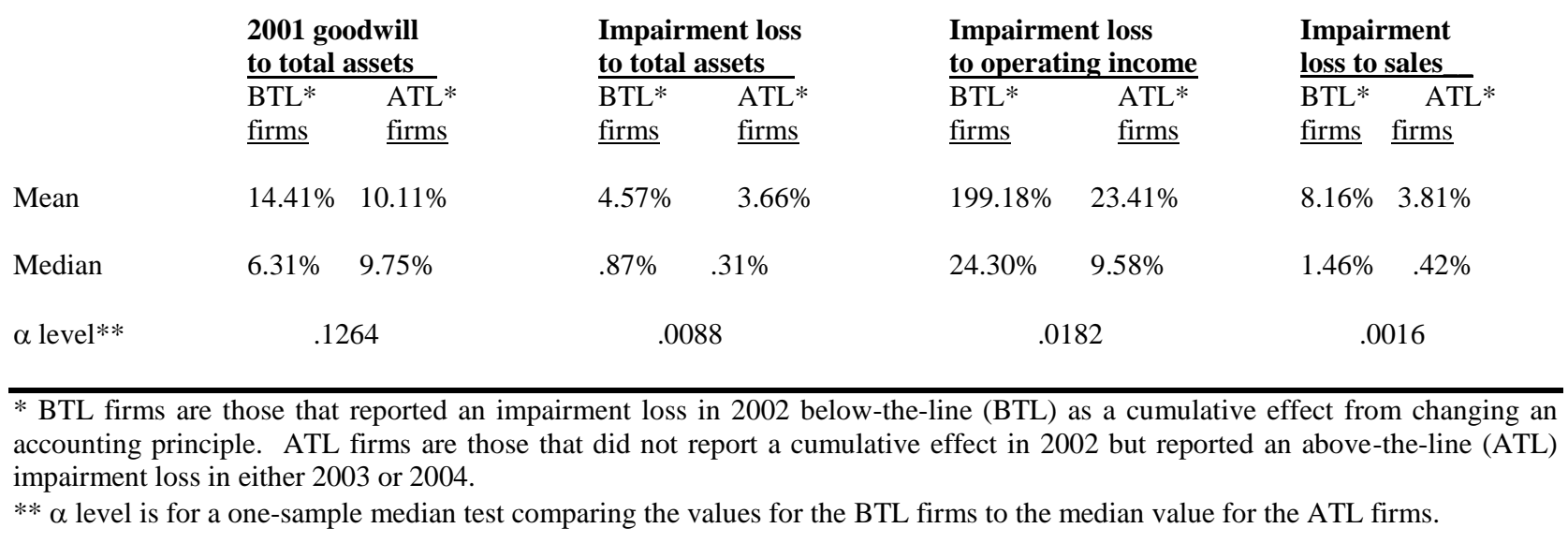

Although both means and medians are presented, medians are used for analyses and statistical testing because means can be unduly influenced by a few extreme values, especially with relatively small sample sizes like the ones examined here (Hintze, 1992). Medians are much less affected by these outlying values. Ratios or percentages are reported rather than absolute amounts to normalize the goodwill balance and impairment loss for the size of an entity. Notice from Table 1 that the 2001 goodwill to total assets ratio is similar between both groups of entities. For the firms reporting a cumulative effect impairment loss in 2002, the median ratio of 2001 goodwill to total assets is $6.31 \%$. For the entities not reporting an impairment loss until a later period, the pre-SFAS No. 142 median goodwill to total assets ratio is $9.75 \%$. These medians do not differ at a statistically significant level ( $\alpha=$ $.1264)$.

Since the 2001 goodwill balances do not differ significantly between the two groups of firms, one might assume that impairment losses on this goodwill would be roughly equal as well. This is not the case, though, as Table 1 reveals that the impairment losses reported below-the-line by the firms in 2002 far exceed the above-the-line losses recognized by the firms reporting write-downs subsequent to 2002. For example, the median ratio of impairment loss to total assets of $.87 \%$ reported as a below-the-line item in 2002 is 2.8 times the size of the median impairment loss to assets $(.31 \%)$ reported above-the-line in 2003 and 2004. These medians differ at a statistically significant level (i.e., $\alpha$ $=.0088$ ). Similar results occurred for the other median ratios providing relative measures of the size of the impairment loss for the two groups.

Clearly, firms took a much larger write-down of their goodwill in the year SFAS No. 142 was adopted than they did in subsequent periods. As noted previously, absent earnings management, there is no reason to believe that the amount of the impairment losses should have differed between 2002 and the later years. The fact that the losses were so much larger in 2002 when they were presented as relatively benign below-the-line charges than they were in 2003 and 2004 as hits to operating income does not prove definitively that management selectively chose the year to report the write-downs. Proving the existence of earnings management requires knowing the mindset of management, which is virtually impossible. Even so, these results provide significant anecdotal evidence that earnings management occurred as managers seemed to "cherry pick" 2002 as the year to record large write-downs of goodwill so that operating income in future years would not be burdened with these charges.

The second main issue addressed in the current study is whether big bath earnings management is occurring with respect to goodwill impairments subsequent to the year of adopting SFAS No. 142. More specifically, has the reporting penalty of presenting impairment losses above-the-line been sufficient to eliminate the big bath earnings observed by Jordan and Clark (2004 and 2005) in the year of adoption? Recall the premise of big bath earnings 
management is that firms will take discretionary hits to income in a period already suffering from depressed earnings. Table 2 shows the mean and median return on assets (ROAs) for entities reporting no goodwill impairment in 2003 or 2004 and for those recognizing a goodwill write-down in 2003 or 2004.

Table 2

Earnings Levels for Impairment and Non-impairment Groups in 2003 and 2004

\begin{tabular}{|c|c|c|c|c|}
\hline & \multicolumn{2}{|c|}{2003} & \multicolumn{2}{|c|}{2004} \\
\hline & $\begin{array}{l}\text { Firms with no } \\
2003 \text { impairment }\end{array}$ & $\begin{array}{l}\text { Firms with a } \\
2003 \text { impairment } \\
\end{array}$ & $\begin{array}{l}\text { Firms with no } \\
2004 \text { impairment } \\
\end{array}$ & $\begin{array}{l}\text { Firms with a } \\
2004 \text { impairment }\end{array}$ \\
\hline Mean ROA & $4.73 \%$ & $-1.08 \%$ & $4.96 \%$ & $-2.11 \%$ \\
\hline Median ROA & $4.02 \%$ & $1.42 \%$ & $4.78 \%$ & $1.82 \%$ \\
\hline$\alpha$ level* & & & & \\
\hline
\end{tabular}

* $\alpha$ level is for a one-sample median test comparing the ROA values for the firms reporting no impairment loss to the median value for the firms reporting an impairment loss. Separate tests are performed within each year.

Table 2 indicates that, relative to the companies taking no goodwill write-downs in 2003 or 2004, the firms reporting impairment losses in these years experienced depressed earnings. For example, the median ROA in 2003 for the non-impairment group of $4.02 \%$ is 2.83 times the median ROA (1.42\%) for the group of firms that recognized an impairment loss that year. The medians differ at a statistically significant level (i.e., $\alpha=.0000$ ). Similar results occurred in 2004 as well.

Rather than relying solely on nonparametric median tests, logit regression models were also used to determine if the decision to take an impairment loss in 2003 or 2004 was related to the level of earnings. Separate models were prepared for 2003 and 2004. The dependent variable in each model was a dichotomous variable with a zero if no impairment loss was taken and a one if a write-down was reported. The lone independent variable in each model was the ROA for the particular year. Table 3 contains the logit models and their summary statistics. Panel A provides the models for the impairment loss years (i.e., 2003 and 2004), while Panel B presents models developed with the ROAs two years prior to the impairment loss years (i.e., 2001 and 2002).

Notice in Panel A that the chi-square statistic for both models is statistically significant (i.e., $\alpha$ levels of .0007 and .0003 , respectively, for the 2003 and 2004 loss year models). This plainly indicates that the probability of the firms taking a discretionary goodwill write-down in a given year is related to the earnings level (ROA) for that year. In addition, the negative sign of the ROA coefficient is as expected and implies an inverse relationship between the level of earnings and the likelihood of taking an impairment hit. The lower the current period earnings, the more likely this subjectively determined charge will be recorded.

In a study of big bath earnings management in relation to discretionary increases in income tax expense due to boosts in the valuation allowance for deferred tax assets, Bauman et al. (2001) found that firms taking these hits had depressed earnings in the current period. They speculated that this alone did not necessarily imply earnings management because depressed earnings could be a sign that the valuation allowance should be increased. They suggested that depressed earnings in the current period only would indicate earnings management while depressed earnings in the current and preceding years provides evidence that future earnings will be depressed as well and, thus, an increase in the valuation allowance is warranted. The same logic applies in the present study dealing with discretionary write-downs of goodwill. 
Table 3

Logit Models for Impairment Loss Years and Two Years Prior

Panel A (For impairment loss years 2003 and 2004):

\begin{tabular}{|c|c|c|c|c|}
\hline & Logit regression equation & $\begin{array}{l}\text { Model } \\
\chi \text {-square }\end{array}$ & $\begin{array}{l}\alpha \\
\text { level }\end{array}$ & $\begin{array}{l}\text { Model } \\
\mathbf{r}^{2} \\
\end{array}$ \\
\hline 2003 Model & $\mathrm{Y}=-1.620307-.116302 * \mathrm{ROA}$ & 11.39 & .0007 & .0642 \\
\hline 2004 Model & $\mathrm{Y}=-1.845309-.111762 * \mathrm{ROA}$ & 13.27 & .0003 & .0753 \\
\hline
\end{tabular}

Panel B (For two years prior to impairment loss years):

\begin{tabular}{lllllll} 
& Logit regression equation & & $\begin{array}{l}\text { Model } \\
\boldsymbol{\chi} \text {-square }\end{array}$ & & $\begin{array}{l}\boldsymbol{\alpha} \\
\text { level }\end{array}$ & $\begin{array}{l}\text { Model } \\
\underline{\mathbf{r}^{2}}\end{array}$ \\
\hline 2001 Model & $\mathrm{Y}=-2.016116-.005971 *$ ROA & & 0.02 & .8996 & .0001 \\
2002 Model & $\mathrm{Y}=-1.838455-.078650 *$ ROA & & 2.47 & .1158 & .0149
\end{tabular}

Note: For the 2003 and 2001 models, the dependent variable is the decision to report an impairment loss in 2003 while the independent variable in the 2003 model is 2003 ROAs and the independent variable in the 2001 model is 2001 ROAs. For the 2004 and 2002 models, the dependent variable is the decision to report an impairment loss in 2004 while the independent variable in the 2004 model is 2004 ROAs and the independent variable in the 2002 model is 2002 ROAs.

Depressed earnings only in the year of an impairment loss suggests big bath earnings management occurred. However, if earnings also suffered in years prior to the year of the impairment loss, strong evidence exists suggesting the write-down was needed and no earnings management took place. The logit models in Panel A of Table 3 have already shown that differences existed in the earnings levels (ROAs) between the impairment and non-impairment firms in the years of the write-downs (i.e., 2003 and 2004). Panel B, though, indicates that just two years prior to the impairment years there was no significant relationship between the earnings level and the likelihood of taking a writedown. That is, the chi-square statistics for both models in Panel B show that the relationship between ROA and the probability of recording a goodwill write-down two years hence is statistically insignificant (i.e., $\alpha$ levels of .8996 and .1158 , respectively, for the 2001 and 2002 models). A two-year lag was used rather than one year because some of the firms reporting impairment losses in 2004 also recognized write-downs in 2003 and a two-year lag insured that no above-the-line impairment losses were recorded in the control years (i.e., 2001 and 2002).

As discussed previously, depressed earnings for several periods represents legitimate support for the decision to take a discretionary write-down of goodwill. This did not occur for the firms in the present study, though, as the entities taking impairment hits to income suffered depressed earnings in the current year but not in prior periods. Although not absolute proof, this result provides substantial evidence that firms continue to practice big bath earnings management via goodwill impairment losses despite the punitive above-the-line treatment that now exists for these write-downs.

\section{SUMMARY AND CONCLUSION}

In 2002, the year SFAS No. 142 was adopted, goodwill impairment losses enjoyed favorable below-the-line treatment on the earnings statement. Subsequent to 2002, goodwill write-downs flow through operating income. Prior research (Bens and Heltzer, 2004) shows that the market reacts more harshly to above-the-line impairment losses than it does to below-the-line write-downs. In addition, Beatty and Weber (2006) suggest that managers consider the distinction between below-the-line and above-the-line presentation to be an important one. This set the stage for possible earnings management as managers had significant discretion in choosing a year for reporting goodwill writedowns. The current study provides compelling evidence that managers "cherry picked" 2002 as the year to report 
large impairment losses, thus minimizing the penalty for reporting these losses by presenting them below-the-line and in addition freeing future periods from the potentially harsh burden of having to report them in operating income.

Prior research (Jordan and Clark, 2004 and 2005) indicates that firms engaged in big bath earnings management relative to goodwill impairment losses recognized in 2002. Having to report goodwill write-downs above-the-line subsequent to 2002 now acts as a deterrent to engaging in big bath earnings management with respect to these impairment losses. Nonetheless, the present study shows that goodwill write-downs continue to exhibit signs of big bath earnings management as, relative to entities not recording impairment losses, firms taking these hits in 2003 and 2004 already suffered from depressed earnings. Management likely anticipated that lowering earnings even further for these impairment losses would do little incremental harm to the market value of their firms' shares.

\section{SUGGESTIONS FOR FUTURE RESEARCH}

Due to time and resource constraints in data collection, the current study examined the reporting of goodwill impairment losses for one distinct group of large firms (i.e., the Fortune 200). As such, its results are not necessarily generalizable to all firms. Using a database that more easily allows the identification of entities with goodwill balances, the current study could be replicated with a randomly selected sample of publicly-traded firms of varying sizes to determine if its results transcend size boundaries.

\section{REFERENCES}

1. Bauman, C.C., M.P. Bauman, and R.F. Halsey, Do Firms Use the Deferred Tax Asset Valuation Allowance to Manage Earnings?, The Journal of the American Taxation Association, Vol. 23, supplement, pp. 27-48, 2001.

2. Beatty, A. and J. Weber, Accounting Discretion in Fair Value Estimates: An Examination of SFAS 142 Goodwill Impairments, Journal of Accounting Research, Vol. 44, No. 2, pp. 257-288, 2006.

3. Bens, D.A. and W. Heltzer, The Information Content and Timeliness of Fair Value Accounting: An Examination of Goodwill Write-Offs Before, During, and After the Implementation of SFAS No. 142, Working paper, University of Chicago, 2004.

4. Bukics, R.M. and B.J. Chapman, The Big Splash: Goodbye Pooling; Hello, Goodwill Impairment Testing, The CPA Journal, Vol. 72, No. 3, pp. 32-36, 2002.

5. Chai, M.L. and S. Tung, The Effect of Earnings-Announcement Timing on Earnings Management, Journal of Business Finance \& Accounting, Vol. 29, Nos. 9 \& 10, pp. 1337-1354, 2002.

6. Chenheiter, M. and N. Melumad, Can Big Bath and Earnings Smoothing Co-exist as Equilibrium Financial Reporting Strategies?, Journal of Accounting Research, Vol. 40, No. 3, pp. 761-796, 2002

7. Elliott, J.A. and W.H. Shaw, Write-offs as Accounting Procedures to Manage Perceptions, Journal of Accounting Research, Vol. 26, supplement, pp. 91-119, 1988.

8. Herz, R., T. Iannaconi, L. Maines, K. Palepu, S. Ryan, K. Schipper, C. Schrand, D. Skinner, and L. Vincent, Equity Valuation Models and Measuring Goodwill Impairment, Accounting Horizons, Vol. 15, No. 2, pp. 161-170, 2001.

9. Hintze, J. Number Cruncher Stastical System Reference Manual, Kaysville, UT, 1992.

10. Jordan, C.E. and S.J. Clark, Big Bath Earnings Management: The Case of Goodwill Impairment Under SFAS No. 142 , Journal of Applied Business Research, Vol. 20, No. 2, pp. 63-69, 2004.

11. Jordan, C.E. and S.J. Clark, Using Goodwill Impairment to Accomplish Big Bath Earnings Management: An Empirical Study, Journal of Business and Economic Perspectives, Vol. 31, No. 1, pp. 80-87, 2005.

12. Lander, G.H. and A. Reinstein, Models to Measure Goodwill Impairment, International Advances in Economic Research, Vol. 9, No. 3, pp. 227-232, 2003.

13. Massoud, M. and C. Raiborn, Accounting for Goodwill: Are We Better Off?, Review of Business, Vol. 24, No. 2, pp. 2632, 2003.

14. McNichols, M. and G.P. Wilson, Evidence of Earnings Management from the Provision for Bad Debts, Journal of Accounting Research, Vol. 28, supplement, pp. 1-31, 1988.

15. Mercer, Z.C., M.R. Crow, and K.W. Patton, Goodwill Valuation Under SFAS 142, The CPA Journal, Vol. 72, No. 2, pp. 22-29, 2002.

16. Peek, E. The Use of Discretionary Provisions in Earnings Management: Evidence from the Netherlands, Journal of International Accounting Research, Vol. 3, No. 2, pp. 27-43, 2004.

17. Visvanathan, G., Deferred Tax Valuation Allowances and Earnings Management, The Journal of Financial Statement Analysis, Vol. 3, No. 4, pp. 6-15, 1998.

18. Walsh, P., R. Craig, and F. Clarke, Big Bath Accounting Using Extraordinary Items Adjustments: Australian Empirical Evidence, Journal of Business Finance \& Accounting, Vol. 18, No. 2, pp. 173-189, 1991. 